\title{
Application of SeDeM expert system in formulation and development of fast disintegrating tablets using starch- glycine conjugates as superdisintegrant
}

\author{
Inderbir SINGH ${ }^{1}$ * (D), Bhawna SHARMA 1 (D), Govind ARORA 1 (iD) \\ 1 Chitkara College of Pharmacy, Chitkara University, Punjab, India \\ * Corresponding Author. E-mail: inderbir.singh@chitakara.edu.in (I.S.); Tel. +91-1762-507085.
}

Received: 10 August 2018 / Revised: 23 May 2019 / Accepted: 05 June 2019

\begin{abstract}
In the present study, microwave assisted synthesis of starch and glycine $(1: 1,1: 3,1: 5)$ conjugates was performed for its application as tablet superdisintegrant. Chemical interactions between starch and glycine were studied by FTIR analysis. Scanning electron microscopy (SEM) was performed to study the surface morphology of conjugates. An innovative tool, SeDeM expert system, was employed to provide index for good compressibility (IGCD) and dispersibility (IGD) against the parameters for the powder under study. IGCD mainly comprises of six main factors (derived from 15 practical pharmaceutical range factors) they initially indicate whether powder has the ability to undergo the process direct compression. IGD (derived from 3 factors) indicates whether the tablets formulated using the given powders are suitable to be used fast disintegrating tablet formulations. SeDeM expert system is an innovative tool for assessing direct compression suitability materials and disintegration potential of the tablets. Optimum ratio of starch and glycine was found to be 1:5 with the IGCD score of 6.4 which was comparatively much better than the other selected ratio's.
\end{abstract}

KEYWORDS: Starch glycine conjugate; superdisintegrant; fast disintegrating tablets; SeDeM expert system.

\section{INTRODUCTION}

Fast disintegrating tablets (FDTs) disintegrate within seconds to release the medicament for faster onset of action. Superdisintegrants are responsible for fast disintegration of these dosage forms. Tablet superdisintegrants normally act by capillary action (wicking), swelling and release of gases. Orally disintegrating tablets are a category of FDTs disintegrating within the oral cavity. Fast disintegration, stability, drug release and tablet strength are some common challenges associated with the formulation of FDTs. SeDeM system mainly focuses over quality by design methodology applied in pre-formulation and formulation development studies for the solid dosage forms. It involves the quantitative determination of certain characteristic parameters helpful in predicting the direct compression suitability of powders. SeDeM expert system has been employed in preformulation studies for developing pediatric ibuprofen orally disintegrating tablets [1],

SeDeM-ODT expert systems has been employed for predicting direct compressing suitability of various excipients in formulating orally disintegrating tablets of ibuprofen [2]. Direct compression suitability of cefuroxime axetil and paracetamol were also studied using SeDeM expert system [3].

Starch and its derivatives are commonly used as binders, fillers and disintegrants in tablet formulations. Various physical and chemical modifications of starches have been reported for improving the compaction and disintegration properties. Modification of starch like conjugation with Neusilin UFL2 [4], magnesium silicate [5], carboxymethlylation of sago and pea starch exhibited improvement in superdisintegration potential compared to the native starches [6].

Domperidone is a peripherally acting dopamine receptor antagonist belonging to class 2 drug (as per BCS classification system) having elimination half life of 5-7 hrs. Domperidone is a weak base exhibiings good solubility at lower $\mathrm{pH}$ and hence is an ideal candidate for developing fast disintegrating tablets [7]. Khan et al 2014 reported domperidone to possess poor direct compression properties and implemented SeDeM expert

How to cite this article: Singh I, Sharma B, Aora G. Application of SeDeM expert system in formulation and development of fast disintegrating tablets using starch-glycine conjugates as superdisintegrant. J Res Pharm. 2019; 23(5): 839-850. 
system for developing FDTs of domperidone [8]. Hence, domperidone is suitable candidate for evaluating the direct compression suitability by SeDeM expert system.

Present study includes the preparation of millet starch-glycine conjugates by microwave assisted technique. The conjugates were characterized by Attenuated Total Reflectance-Fourier Transform IR (ATRFTIR) spectroscopy and Scanning Electron Microscopy (SEM) techniques. Prepared conjugates were employed for formulating FDTs. Direct compression suitability of starch-glycine conjugates was accessed from five factors viz. bulk density, tapped density, inter particle porosity, carr's index, cohesion index, hausner ratio, angle of repose, powder flow, loss on drying, hygroscopicity, particle size $<50 \mu \mathrm{m}$ and homogeneity index. However, the disintegration potential of the FDTs was accessed from disintegration time, wetting time and water absorption ration of the FDTs. SeDeM diagrams for native millet starch and millet starch-glycine conjugates and their respective FDTs were prepared for studying their direct compression suitability and disintegration potential.

\section{RESULTS}

Physical mixtures of millet starch and glycine in ratios of 1:1, 1:3, and 1:5 were subjected to microwave treatment for the preparation starch glycine conjugates which were used as tablet superdisintegrant for formulating FDTs of domperidone as per Table 1. Surface morphology of the native millet starch-glycine (1:5) conjugate was studied by scanning electron microscopy technique. SEM micrographs (Figure 1) of native millet starch show the presence of regular round discrete granular structures in the size range of 5-50 micrometers.

Table 1. Formulation of FDTs of domperidone using different ratios of Starch:Glycine as tablet superdisintegrants.

\begin{tabular}{lllll}
\hline Ingredients & FDT S & FDT SG11 & FDT SG13 & FDT SG15 \\
\hline Domperidone & 10 & 10 & 10 & 10 \\
Avicel 101 & 83 & 83 & 83 & 83 \\
Starch & 5 & - & - & - \\
Starch:Glycine (1:1) & - & 5 & - & - \\
Starch:Glycine (1:3) & - & - & 5 & - \\
Starch:Glycine (1:5) & - & - & - & 5 \\
Talc & 1 & 1 & 1 & 1 \\
Magnesium stearate & 1 & 1 & 1 & 1 \\
\hline
\end{tabular}

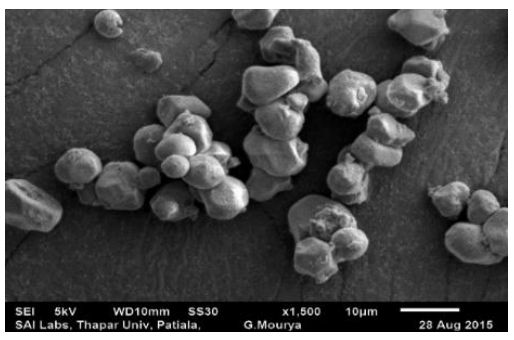

A

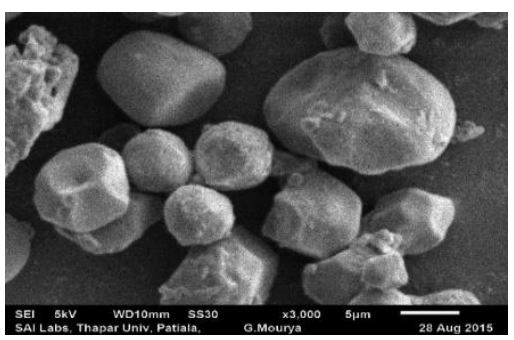

C

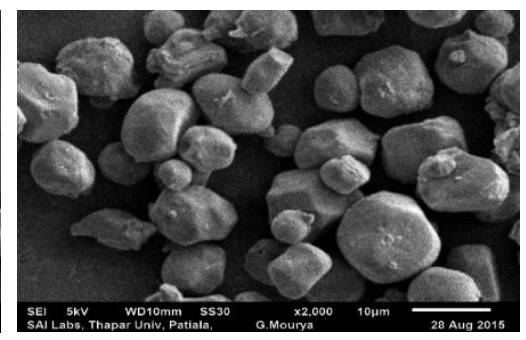

B

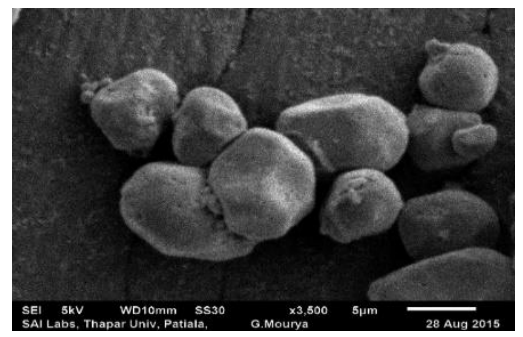

D

Figure 1. SEM images of native millet starch at different magnifications (A) x1500, (B) x2000, (C) x3000, (D) x3500. 
SEM micrographs (Figure 2) of the native millet starch-glycine conjugates reveals the distortion of regular round structure of native millet starch and the presence of surface roughness. The surface roughness could be due to interparticulate voids and channels which are further responsible for wicking behavior and superdisintegrant property of starch-glycine conjugates.

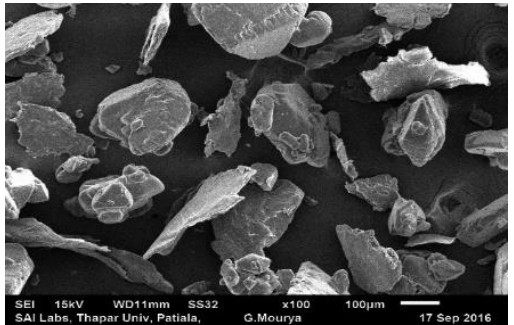

A

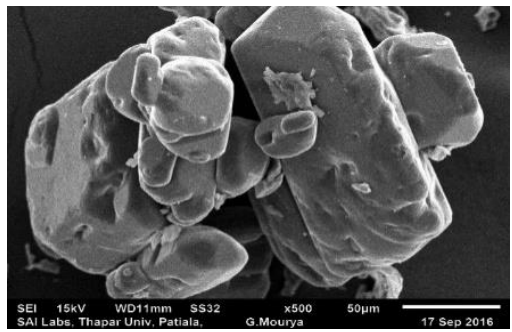

C

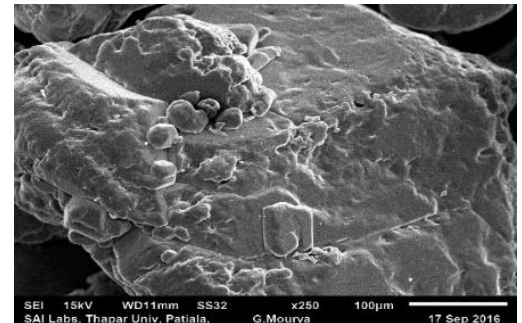

B

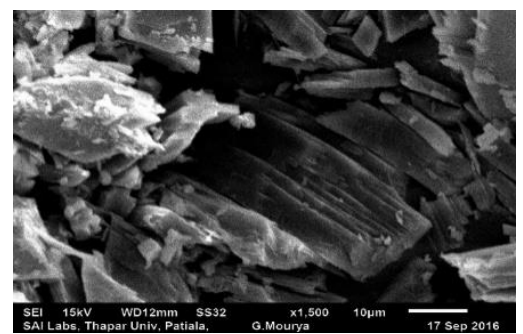

D

Figure 2. SEM images of starch glycine (1:5) conjugates at different magnifications (A) x100, (B) x250, (C) x500, (D) x1500.

FTIR spectral peaks of starch, glycine and their conjugates are shown in Figure 3. Starch exhibited peak at around $3200 \mathrm{~cm}^{-1}$ is due to $\mathrm{OH}$ groups in starch molecules, $\mathrm{C}-\mathrm{H}$ stretching at $2925 \mathrm{~cm}^{-1}, \mathrm{C}=\mathrm{O}$ stretching at $1640 \mathrm{~cm}^{-1}, \mathrm{CH}_{2}$ symmetrical stretching vibration observed at $1370 \mathrm{~cm}^{-1}$ and $\mathrm{C}-\mathrm{C}, \mathrm{C}-\mathrm{O}, \mathrm{C}-\mathrm{O}-\mathrm{C}, \mathrm{C}-\mathrm{O}-\mathrm{H}$ stretching at $1350 \mathrm{~cm}^{-1}-850 \mathrm{~cm}^{-1}$. FTIR spectra of glycine shown peak at 3200-3400 $\mathrm{cm}^{-1}$ (primary amine stretching vibrations), $3000 \mathrm{~cm}^{-1}$ (OH stretching vibrations of carboxylic acid) and 1550-1650 $\mathrm{cm}^{-1}(\mathrm{~N}-\mathrm{H}$ bending vibrations). Starch glycine conjugates exhibit broad peak between $3200-3600 \mathrm{~cm}^{-1}$ and $1600-1800 \mathrm{~cm}^{-1}$ corresponding to the incorporation of carboxylic acid group in the structure of starch and formation of starch: glycine conjugate.

\subsection{Characterization of domperidone}

Domperidone was characterized using twelve selected parameters as per the SeDeM expert system (Figure 4). The data presented in Table 2 indicates the inability of the selected API to comply with factors viz. dimension, compressibility and powder flow. Moreover, the index of good compressibility of domperidone was below 5 . Hence there is need to improve these properties of the selected API in order to prepare its FDTs.

For validating SeDeM system, different batches of FDTs of domperidone were prepared using fixed concentration of different ratios of starch and glycine $(1: 1,1: 3,1: 5)$ as tablet superdisintegrant. For preparing SeDeM-FDT expert diagram, the pre compression tableting powder blends of different FDTs were used for computing different parameters indicative of dimensions, compressibility, powder flow, lubricity/stability and lubricity/dosage. Furthermore, the prepared FDTs (FDT 1:1, FDT 1:3, FDT 1:5) were evaluated for factor called disintegration ability by studying three parameters viz. disintegration time, water absorption ratio and wetting time. 
A

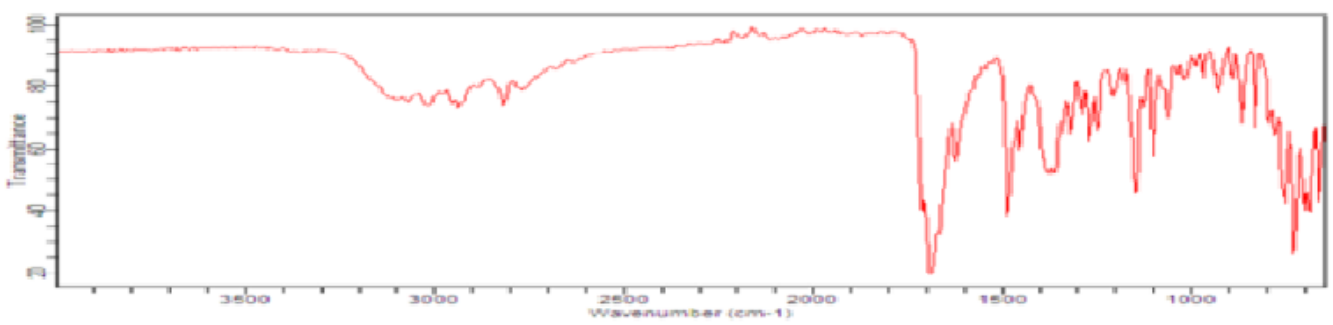

B

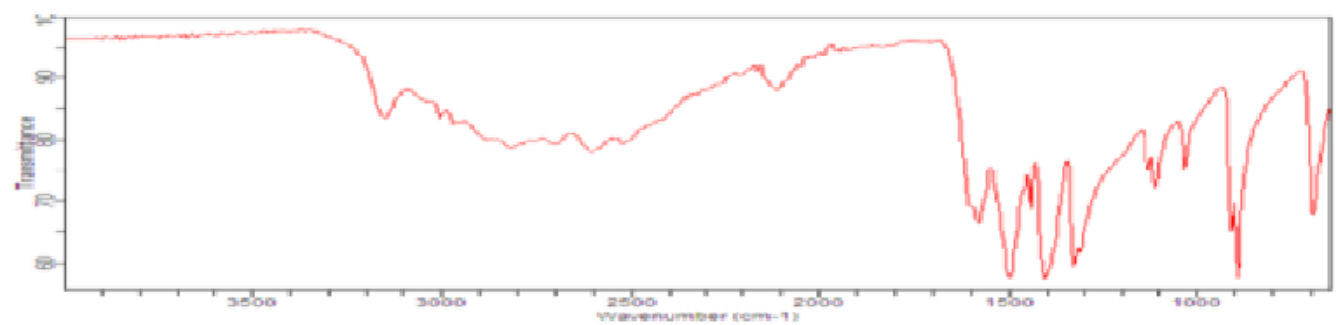

$\mathrm{C}$

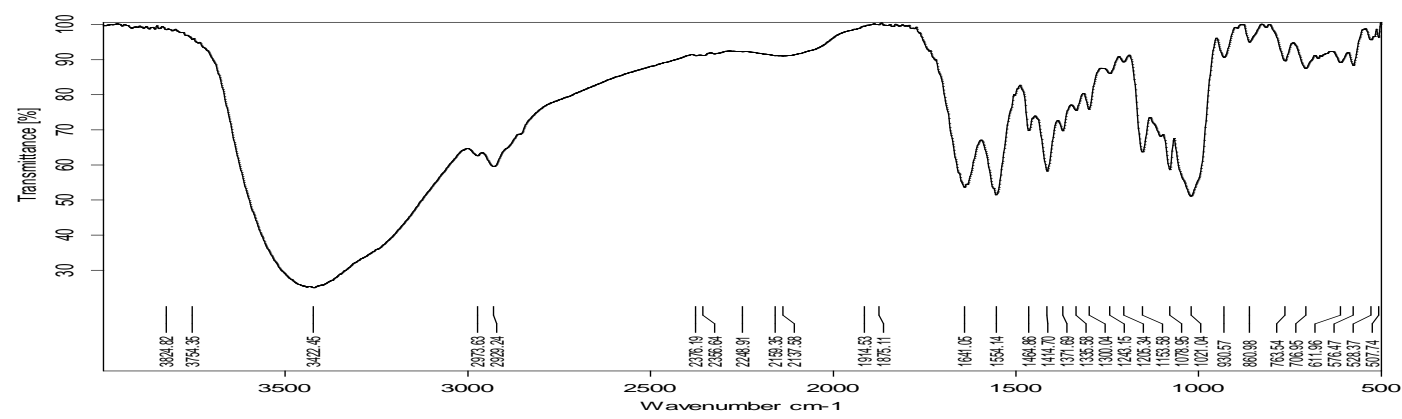

D

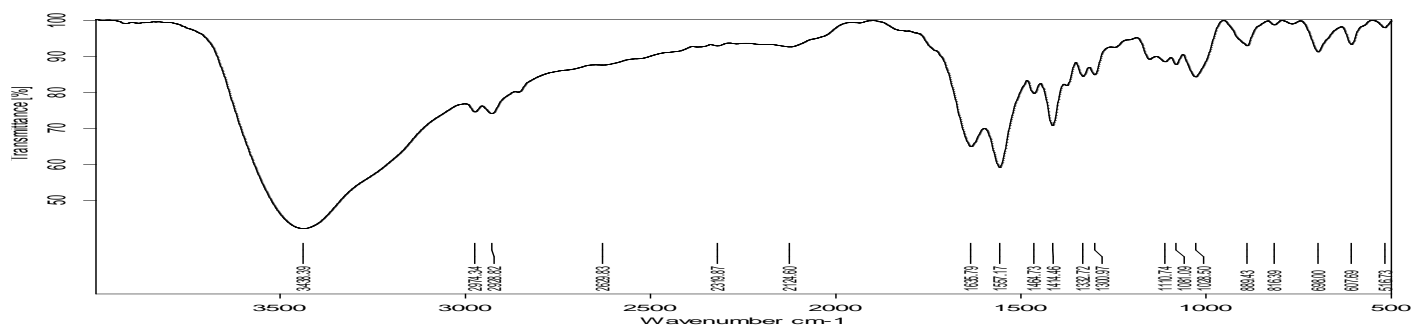

E

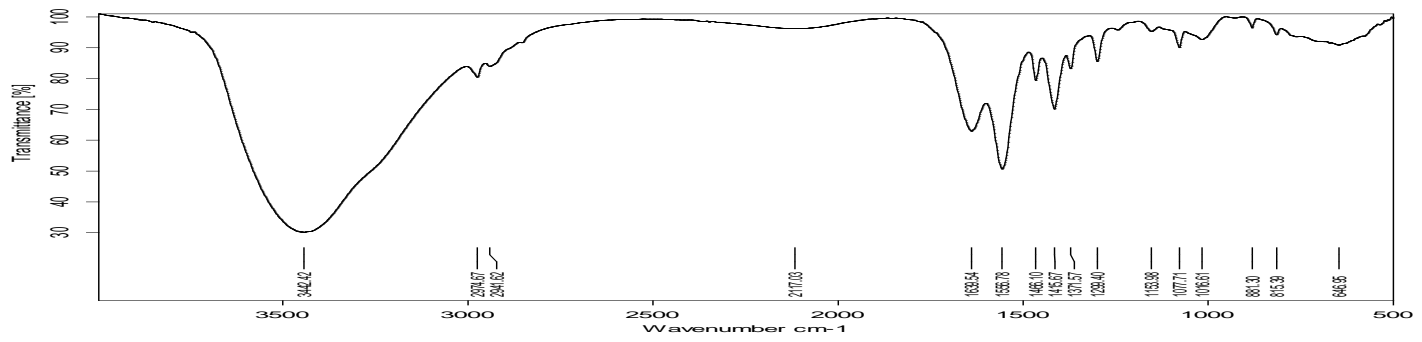

F

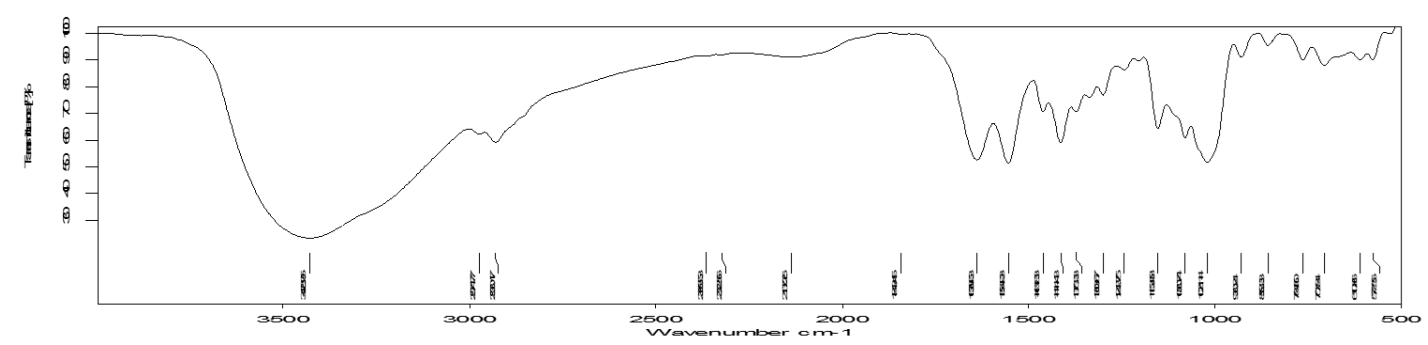

Figure 3. FTIR of different samples, (A) Glycine, (B) Domperidone, (C) Starch:Glycine conjugate (1:1), (D) Starch:Glycine conjugate (1:3), (E) Starch:Glycine conjugate (1:5), (F) Starch. 


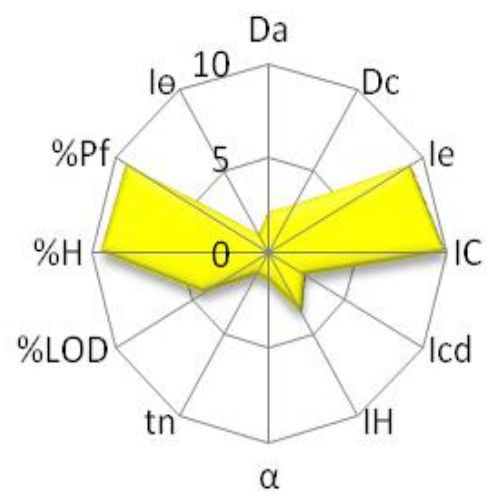

Figure 4. SeDeM diagram of pure domperidone.

Table 2. SeDeM parametric evaluation of domperidone.

\begin{tabular}{lcc}
\hline \multirow{2}{*}{ Parameter } & \multicolumn{2}{c}{ Results } \\
\cline { 2 - 3 } & $\mathbf{V}$ & $\mathbf{R}$ \\
\hline Bulk density (Da) & 0.214 & 2.14 \\
Tapped density (Dc) & 0.285 & 2.85 \\
Inter particle porosity (Ie) & 1.104 & 9.2 \\
Carr index (IC) & 0.249 & 9.95 \\
Cohesion index (Icd) & 48 & 2.4 \\
Hausner ratio (IH) & 1.880 & 3.73 \\
Angle of repose (a) & 42.35 & 1.53 \\
Powder flow (t ${ }^{n}$ ) & 17.22 & 1.39 \\
Loss on drying (\%LOD) & 5.74 & 4.26 \\
Hygroscopicity (\%H) & 1.12 & 9.44 \\
Particles < 50 (\%Pf) & 3.84 & 9.232 \\
Homogenity index (IO) & 0.0022 & 1.1 \\
\hline
\end{tabular}

\subsection{SeDeM diagram}

SeDeM expert system involves 15 parameters through which the SeDeM expert system diagram is developed (Figure 5). This diagram involves 15 polygonal sides through which these parameters are studied. If the value exceeds 5 in the diagram represents have high ability to be directly compressed. If the value declines from 5 then it shows that excipients or product need to be improved for direct compression purpose.

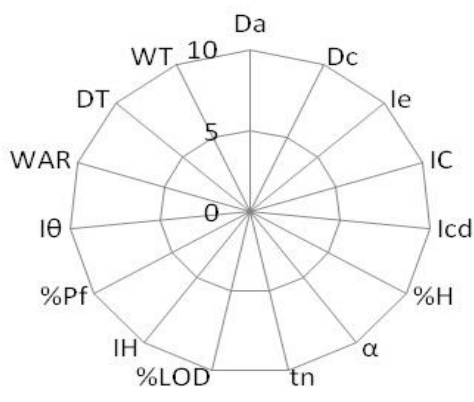

Figure 5. Blank SeDeM ODT expert system diagram. 
SeDeM expert system could be used for evaluating the direct compression suitability of the synthesized conjugates for developing ODT formulations. From the index values we could also calculate the optimal or the best ratio which give the optimum value of the IGCD between 10-0.

Three ratios (1:1, 1:3, 1:5) of starch glycine conjugates were studied under respective indexes employing 15 parameters SeDeM expert system (Table 3). SeDeM diagrams of tableting blends for preparing FDTs employing starch and glycine (1:1) and (1:3) as tablet superdisintegrant are shown in Figure 6 and Figure 7. As the ratios were characterized it was seen that the 1:5 showed good results in respect to the compressibility and flowability as compared to the others ratios. The results were compared on the basis of the graphically representation of the ratios over the pie-diagram. The optimum ratio which was concluded was the 1:5. As 1:5 values were more appropriate according to the ratios of the maximum area of the circle $(\mathrm{r}=10)$ to the area of the polygon which showed a better pie-diagram as compared to the other ratios as explained in Figure 8, SeDeM-ODT diagram of tableting blend for preparing FDTs employing starch and glycine (1:5) as tablet superdisintegrant.

Table 3. Parameters and equations for preparing SeDeM diagrams.

\begin{tabular}{|c|c|c|c|c|c|}
\hline $\begin{array}{l}\text { Factor/ } \\
\text { Incidence }\end{array}$ & $\begin{array}{l}\text { Parameters with symbols } \\
\text { and units }\end{array}$ & Equation & $\begin{array}{c}\text { Limit } \\
\text { value }(\mathrm{V})\end{array}$ & $\begin{array}{l}\text { Radius } \\
\text { (r) }\end{array}$ & $\begin{array}{c}\text { Factor } \\
\text { Applied to V }\end{array}$ \\
\hline \multirow{2}{*}{ Dimension } & $\begin{array}{c}\text { Bulk density (Da) } \\
(\mathrm{g} / \mathrm{ml})\end{array}$ & $\mathrm{Da}=\mathrm{P} / \mathrm{V}_{\mathrm{a}}$ & $0-1$ & $0-10$ & $10 \mathrm{~V}$ \\
\hline & $\begin{array}{l}\text { Tapped density (Dc) } \\
(\mathrm{g} / \mathrm{ml})\end{array}$ & $\mathrm{Dc}=\mathrm{P} / \mathrm{V}_{\mathrm{c}}$ & $0-1$ & $0-10$ & $10 \mathrm{~V}$ \\
\hline \multirow{3}{*}{ Compressibility } & Inter particle porosity (Ie) & $\begin{array}{c}\mathrm{Ie}=\mathrm{Dc}-\mathrm{Da} / \\
\mathrm{Dc} \times \mathrm{Da}\end{array}$ & $0-1.2$ & $0-10$ & $10 \mathrm{~V} / 1.2$ \\
\hline & $\begin{array}{c}\text { Carr index }(\mathrm{IC}) \\
(\%)\end{array}$ & $\begin{array}{c}\mathrm{IC}=(\mathrm{Dc}- \\
\mathrm{Da} / \mathrm{Dc})\end{array}$ & $50-0$ & $0-10$ & $10-(\mathrm{V} / 5)$ \\
\hline & $\begin{array}{c}\text { Cohesion Index (Icd) } \\
(\mathrm{N})\end{array}$ & Experimental & $0-200$ & $0-10$ & $\mathrm{v} / 20$ \\
\hline \multirow{3}{*}{ Flowability } & Hausner Ratio (IH) & $\mathrm{IH}=\mathrm{Dc} / \mathrm{Da}$ & $3-0$ & $0-10$ & $10-(10 \mathrm{~V} / 3)$ \\
\hline & Angle of repose $(\alpha)$ & $a=\tan ^{-1} \mathrm{~h} / \mathrm{r}$ & $50-0$ & $0-10$ & $10-(\mathrm{V} / 5)$ \\
\hline & $\begin{array}{l}\text { Powder Flow }\left(\mathrm{t}^{n}\right) \\
(\mathrm{sec})\end{array}$ & Experimental & $20-0$ & $0-10$ & $10-(\mathrm{V} / 2)$ \\
\hline \multirow{2}{*}{ Lubricity/Stability } & $\begin{array}{c}\text { Loss of drying (\%LOD) } \\
(\%)\end{array}$ & Experimental & $1.5-0$ & $0-10$ & $10-(10 \mathrm{~V} / 1.5)$ \\
\hline & $\begin{array}{c}\text { Hygrocsopicity }(\% \mathrm{H}) \\
(\%)\end{array}$ & Experimental & $20-0$ & $0-10$ & $10-(\mathrm{V} / 2)$ \\
\hline \multirow{2}{*}{ Lubricity/Dosage } & $\begin{array}{c}\text { Particle }<50(\% \mathrm{Pf}) \\
(\%)\end{array}$ & Experimental & $50-0$ & $0-10$ & $10-(\mathrm{V} / 5)$ \\
\hline & Homogenity Index (IӨ) & Equation 1 & $0-0.02$ & $0-10$ & $500 \mathrm{~V}$ \\
\hline \multirow{3}{*}{$\begin{array}{l}\text { Disintegration } \\
\text { ability }\end{array}$} & $\begin{array}{c}\text { Water absorption ratio } \\
\text { (WAR) } \\
(\%)\end{array}$ & Experimental & $0-40$ & $0-10$ & $10 \mathrm{~V} / 40$ \\
\hline & $\begin{array}{l}\text { Disintegration time (DT) } \\
(\mathrm{sec})\end{array}$ & Experimental & $0-20$ & $0-10$ & $10 \mathrm{~V} / 20$ \\
\hline & $\begin{array}{c}\text { Wetting time (WT) } \\
(\mathrm{sec})\end{array}$ & Experimental & $0-100$ & $0-10$ & $\mathrm{~V} / 10$ \\
\hline
\end{tabular}

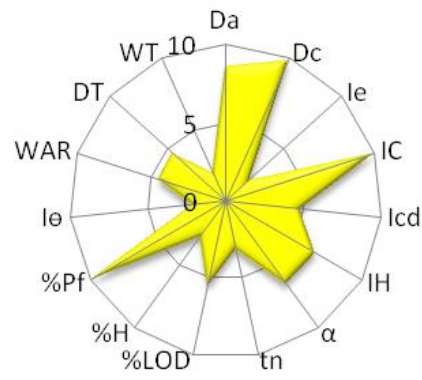

Figure 6. SeDeM-FDT diagram of tableting blend for preparing FDTs employing starch and glycine (1:1) as tablet superdisintegrant. 


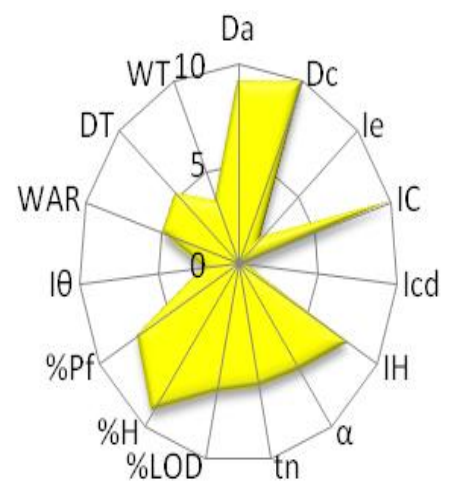

Figure 7. SeDeM-FDT diagram of tableting blend for preparing FDTs employing starch and glycine (1:3) as tablet superdisintegrant.

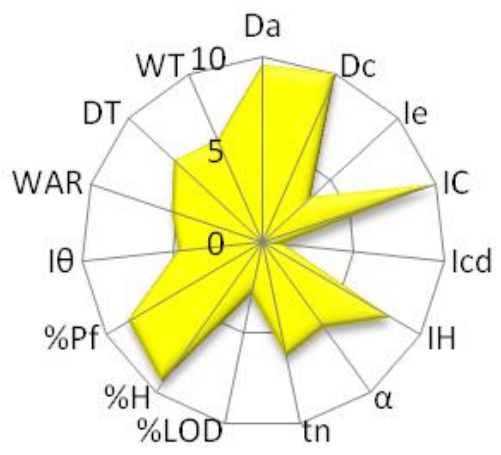

Figure 8. SeDeM-FDT diagram of tableting blend for preparing FDTs employing starch and glycine (1:5) as tablet superdisintegrant.

The second ratio which was found appropriate after the 1:5 was the ratio 1:3 as its IPP and IGCD values were better than that of the 1:1. As shown in Figure 7, SeDeM-ODT diagram of tableting blend for preparing FDTs employing starch and glycine (1:3) as tablet superdisintegrant.

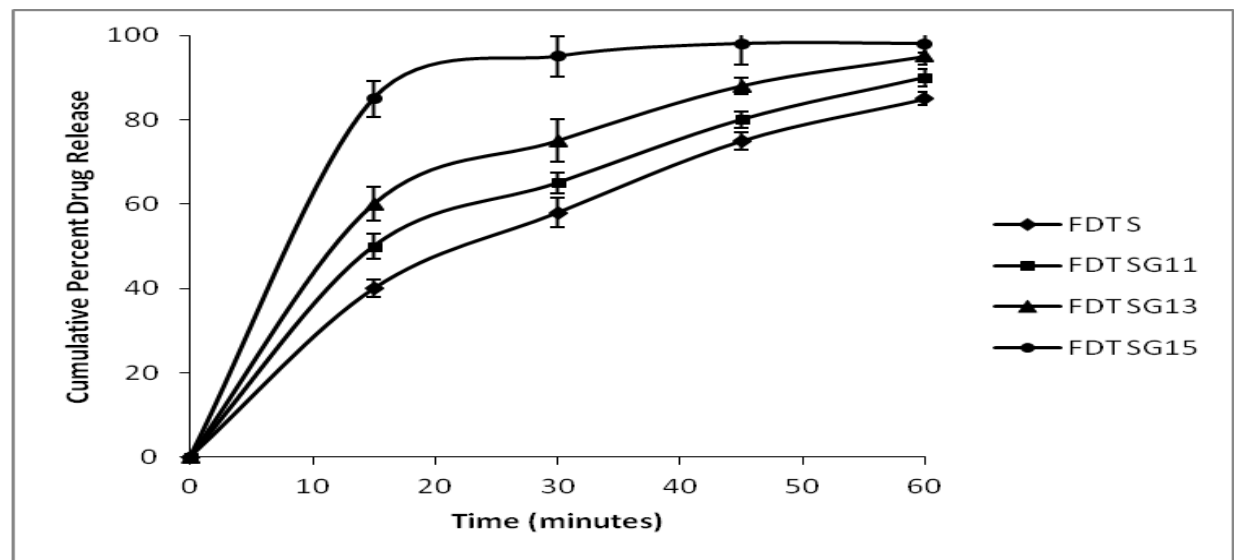

Figure 9. In vitro dissolution of the formulated FDTs.

The SeDeM diagram for the respective ratios was made with the help of the values as shown in the Table 4. IPP and IGCD values for the different ratios are depicted in Table 5. In vitro dissolution profiles of the formulated FDTs are depicted in Figure 9. The evaluation results of the formulation FDTs are depicted in Table 6. The hardness, friability and content uniformity were found to be ranging between $4.0 \pm 0.45$ to $5.1 \pm 0.84$ $\mathrm{kg} / \mathrm{cm}^{2}, 0.48 \pm 0.07$ to $0.76 \pm 0.03 \%, 98.86 \pm 0.50$ to $99.50 \pm 0.83 \%$ respectively. 
Table 4. $\mathrm{R}$ and $\mathrm{V}$ values for preparing SeDeM diagrams of different ratios of starch and glycine.

\begin{tabular}{cccccccc}
\hline \multirow{2}{*}{ S. No. } & Parameters & \multicolumn{2}{c}{$\mathbf{1 : 1}$} & \multicolumn{2}{c}{$\mathbf{1 : 3}$} & \multicolumn{2}{c}{$\mathbf{1 : 5}$} \\
\cline { 3 - 8 } & & $\mathbf{V}$ & $\mathbf{R}$ & $\mathbf{V}$ & $\mathbf{R}$ & $\mathbf{V}$ & $\mathbf{R}$ \\
\hline 1 & Da & 0.86 & 8.6 & 0.98 & 9.8 & 0.95 & 9.5 \\
2 & Dc & 0.98 & 9.8 & 0.99 & 9.9 & 0.99 & 9.9 \\
3 & Ie & 0.24 & 2.0 & 0.23 & 1.91 & 0.43 & 3.58 \\
4 & IC & 0.122 & 9.97 & 0.01 & 9.99 & 0.04 & 9.99 \\
5 & Icd & 9.5 & 4.75 & 10 & 0.5 & 30.2 & 1.15 \\
6 & IH & 1.025 & 6.584 & 0.62 & 7.94 & 0.54 & 8.2 \\
7 & a & 17.52 & 6.496 & 17.13 & 6.58 & 21.29 & 5.75 \\
8 & tn & 13.85 & 3.1 & 7.4 & 6.3 & 7.25 & 6.37 \\
9 & \%OD & 4.5 & 5.5 & 3.4 & 6.5 & 2.9 & 7.6 \\
10 & \%H & 14.1 & 2.75 & 1.8 & 9.1 & 1.2 & 9.4 \\
11 & \%Pf & 3.12 & 9.375 & 14 & 7.2 & 7.5 & 8.5 \\
12 & Iө & 0.0076 & 2.12 & 0.0042 & 2.125 & 0.0092 & 4.62 \\
13 & WAR & 45 & 4.5 & 49 & 4.9 & 52 & 5.2 \\
14 & DT & 32 & 4.6 & 28 & 5.2 & 19 & 6.5 \\
15 & WT & 24 & 2 & 24 & 3.4 & 15 & 6 \\
\hline & & & & & & & \\
& & & 24.5 &
\end{tabular}

Table 5. IPP and IGCD values for the different ratiosof starch and glycine.

\begin{tabular}{ccc}
\hline Ratio & IPP & IGCD \\
\hline $1: 1$ & 5.22 & 5.0 \\
$1: 3$ & 5.36 & 5.2 \\
$1: 5$ & 6.69 & 6.4 \\
\hline
\end{tabular}

Table 6. Evaluation results of the formulated FDTs.

\begin{tabular}{|c|c|c|c|c|c|}
\hline Conjugates & $\begin{array}{l}\text { Hardness } \\
\left(\mathrm{Kg} / \mathrm{cm}^{2}\right)\end{array}$ & $\begin{array}{c}\text { Friability } \\
\text { (\%) }\end{array}$ & $\begin{array}{l}\text { Diameter } \\
(\mathrm{mm})\end{array}$ & $\begin{array}{l}\text { Thickness } \\
\text { (mm) }\end{array}$ & $\begin{array}{l}\text { Content uniformity } \\
\qquad(\%)\end{array}$ \\
\hline FDT S & $4.0 \pm 0.45$ & $0.76 \pm 0.03$ & $6.01 \pm 0.02$ & $3.52 \pm 0.83$ & $99.50 \pm 0.83$ \\
\hline FDT SG 11 & $5.0 \pm 0.30$ & $0.48 \pm 0.07$ & $6.00 \pm 0.01$ & $3.50 \pm 0.04$ & $99.01 \pm 0.35$ \\
\hline FDT SG 13 & $5.1 \pm 0.84$ & $0.50 \pm 0.10$ & $6.02 \pm 0.03$ & $3.58 \pm 0.03$ & $98.86 \pm 0.50$ \\
\hline FDT SG 15 & $4.90 \pm 0.75$ & $0.51 \pm 0.08$ & $6.00 \pm 0.01$ & $3.54 \pm 0.05$ & $98.90 \pm 0.90$ \\
\hline
\end{tabular}

\section{DISCUSSION}

Microwave technology was employed for preparing the conjugates of starch and glycine. The conjugates were prepared in different ratios of starch and glycine viz. 1:1, 1:3 and 1:5. The surface morphology of the conjugates was study by SEM techniques. The SEM micrograph indicates the presence of surface roughness, voids and channels responsible for superdisintegrant property of the conjugates. FTIR analysis indicates the interaction of functional group of starch and glycine to form conjugates. Goel et al 2009 investigated Chitosan Glycine mixture to possess tablet superdisintegrant properties and prepared and evaluated oral dispersible tablets of ondansetron employing these conjugates [9]. Starch-Neusilin [4], StarchMetal silicate [10], Starch-Silicone dioxide [11] have been prepared, evaluated and established as tablet superdisintegrant by our research group. The interaction of glycine with starch to form conjugates was conducted with an aim to enhance the wicking ability which further increases the tablet disintegration 
property of the biopolymer for being used in the development of fast disintegrating tablets. Domperidone was found to possess poor flowability and poor compressibility as per the SeDeM expert system. Khan et al 2014 also reported domperidone to possess poor direct compression properties and implemented SeDeM expert system for developing FDTs of domperidone [8]. SeDeM pie diagrams of different ratios of conjugates of starch and glycine were also prepared for computing IPP and IGCD. The prepared conjugates were employed for preparing FDTs of domperidone. The formulated FDTs were evaluated for various tablet evaluation parameters. SeDeM expert system was used to access the direct compression suitability of the powder blends. SeDeM expert system is an innovative tool in preformulation studies for pharmaceutical product development. Pharmaceutical API and excipients are evaluated as per SeDeM expert system for direct compression suitability. The desired property of the API could be modified using defined excipients as per the expert system. SeDeM expert system has been proved to be suitable method for predicting the direct compression suitability of materials.

\section{CONCLUSION}

Starch-gylcine conjugates were prepared by microwave technique. The conjugates were characterized by FTIR and SEM techniques. FDTs were formulated for evaluating tablet superdisintegrant property of the conjugates. SeDeM expert system was employed for evaluating direct compression suitability of strach-glycine conjugates for preparing FDTs of domperidone. SeDeM expert system was porposed as a preformulation tool forevaluating direct compression suitability of excipients for developing FDTs.

\section{MATERIALS AND METHODS}

\subsection{Materials}

Domperidone and millet starch were kindly gifted by Ipzha Pharmaceuticals, Patiala, Punjab, India. Glycine was purchased from Merck, Mumbai, India. Avicel 102 was kindly gifted by FMC biopolymers, Ireland. All chemicals and reagents used in the study were of analytical grade.

\subsection{Preparation and characterization of starch glycine conjugates}

The conjugates of millet starch and glycine were prepared by microwave irradiation method in which physical mixtures of millet starch and glycine in ratios of 1:1, 1:3, 1:5 were subjected to microwave (Model EM20SSLN, Electrolux, India) radiations at 590 watt for heating of 3 minutes (three cycles) with 1 minute intermediate cooling.

The prepared conjugates were characterized by Attenuated Total Reflectance-Fourier Transform IR Spectroscopy (ATR-FTIR) (Alpha, Bruker, Japan) and Scanning Electron Microscopy (SEM) (Model S 4300 SE/N SEM, Hitachi High Technologies, and Singapore) techniques. The ATR-FTIR samples were scanned in the spectral region of $4000 \mathrm{~cm}^{-1}$ to $400 \mathrm{~cm}^{-1}$ by $\mathrm{KBr}$ pellet method. The samples were stuck on a specimen holder using a silver plate and then coated with palladium in a vacuum evaporator.

\subsection{Evaluation of material as per SeDeM expert system}

For determining the direct compression suitability and disintegration ability domperidone, native millet starch and starch-glycine conjugates were evaluated for different parameters as per the SeDeM expert system. After experimental determination, the numerical values (v) of all the parameters were converted to radius value ( $\mathrm{r}$ ) by applying a specific factor as shown in Table 4 . The direct compression suitability of the materials could be accessed from five factors viz. dimensions, compressibility, powder flow, lubricity/stability and lubricity/dosage. Basic parameters for studying direct compression suitability through SeDeM expert system are bulk density, tapped density, inter particle porosity, carr's index, cohesion index, hausner ratio, angle of repose, powder flow, loss on drying, hygroscopicity, particle size $<50 \mu \mathrm{m}$ and homogeneity index. The tablet disintegration potential of formulated fast disintegrating tablets (FDT) was correlated with disintegration time, wetting time and water absorption ration of the FDTs.

Disintegration Time (DT). In vitro studies for disintegration time was carried out for the tablets was determined using USP disintegration apparatus (EI Product, Panchkula, India) using 0.1NHCl (pH 1-2, 900 $\mathrm{mL}$ at $37^{\circ} \mathrm{C}$ ) as the disintegrating medium.

Wetting Time $(\mathrm{WT})$. A piece of tissue paper $(10.75 \times 12 \mathrm{~mm})$ folded twice was placed in a culture dish $(d=6.5 \mathrm{~cm})$ containing $6 \mathrm{~mL}$ of water (containing a water soluble dye eosin). A tablet was carefully placed on 
the surface of tissue paper and the time required for water to reach the upper surface of the tablet was noted as the wetting time.

Water Absorption Ratio (WAR) same steps were used for the wetting time was used for the water absorption ratio. Initial tablet weighed $(\mathrm{Wa})$ was measured before its placement on the wet tissue and the final weight $(\mathrm{Wb})$ was taken after complete wetting. Water absorption ratio was determined using the equation (Eq. 1) [7].

$$
\mathrm{WAR}=(\mathrm{Wb}-\mathrm{Wa}) / \mathrm{Wb} \times 100
$$

\subsection{Determination of numerical index parameters}

When radius value all the parameters is 10 , SeDeM diagram contains a regular polygon shape which is drawn by inters joining the radius values to the linear segments. The fifteen parameter SeDeM diagram is an indicative of suitability of the powder for good compressibility and hence the prepared tablets for good disintegration ability. Three numerical index parameters could be assessed from the SeDeM diagram: index parameter (IP), index profile parameter (IPP) and index of good compressibility and disintegration ability (IGCD).

Index Parameter $(\mathrm{IP})=\mathrm{P} \geq 5 / \mathrm{Pt}$

$P \geq 5$ represents a fix number of parameters having radius value equal or greater than 5

$\mathrm{Pt}$ denotes total number of parameters studied

Index Profile Parameter (IPP) = mean of radius of all the parameters studied

Index of Good Compressibility and Disintegration ability (IGCD) = IPP xf

$F$ represents the area of the polygon in the SeDeM diagram

Index of good compressibility and disintegration ability (IGCD) is an indicator of aptitude of a powder material for compressibility and subsequently the tablet prepared using the same powder for disintegration ability. IGCD value is experienced exceeding five. It extensively reflects towards good compressibility and disintegration ability against the tablets formulated. Excipients and pharmaceutical actives could be screened for compressibility and disintegration ability based upon the numerical index parameters derived from SeDeM diagram. Hence, SeDeM expert system could be considered as an effective tool during preformulation studies for assessing the compression and disintegration ability of pharmaceutical materials. It significantly reduces the number trials for screening of materials during preformulation and development stage of solid pharmaceutical dosage forms [8].

\subsection{Preparation of FDTs}

Fast disintegrating tablets of domperidone $(10 \mathrm{mg})$ were formulated by direct compression method using millet starch and the millet starch-glycine conjugates as superdisintegrant, according to the formula given in Table 1. Specified quantities of drug, diluent, and superdintegrant were weighed and passed through 60 mesh sieve ( $250 \mu \mathrm{m}$ aperture size). The ingredients were mixed for 15 to 20 minutes in a sealable polybag by tumbling method. The powder mixture was lubricated with a talc and magnesium stearate by additional 5 minutes mixing. The lubricated powder mixture was compressed into FDTs using multipunch tableting machine (AK Industries, Nakodar, Punjab, and India) employing $6.75 \mathrm{~mm}$ biconcave round die-punch tooling.

\subsection{Evaluation of FDTs}

Formulated batches of FDTs were evaluated for disintegration time, wetting time and water absorption ratio tests as described in section 5.3.

\subsubsection{Diameter and Thickness}

A calibrated vernier caliper (M/s Mitutoyo Corp., Japan) was used for diameter and thickness evaluation of tablets.

\subsubsection{Hardness}

The force required to break the tablet diametrically was determined using hardness tester (Perfit, India). 


\subsubsection{Friability}

Friability of 20 tablets was measured using Roche Friabilator (Model 902, EI, and Panchkula, India). Tablets were weighed and rotated at $25 \mathrm{rpm}$ for 4 minutes. Tablets were reweighed after removal of fines (dusted) and the percentage of weight loss was calculated.

\subsubsection{Content uniformity}

The content uniformity was assessed according to USP method. Ten tablets were pulverized and quantity of powder equivalent to $10 \mathrm{mg}$ of domperidone was shaken with $100 \mathrm{~mL}$ of $0.1 \mathrm{~N} \mathrm{HCl}$ for 30 minutes. The contents were filtered through a $0.45 \mu \mathrm{m}$ membrane filter, diluted, and analyzed at $284 \mathrm{~nm}$ using a UV/VIS double beam spectrophotometer (Model 2202, Systronics, Ahmedabad, India).

\subsubsection{In Vitro dssolution study}

In vitro dissolution of the fast disintegrating tablets was studied in USP XXIV dissolution apparatus II (DS 8000, Lab India, Pune, India) employing a paddle stirrer at $50 \mathrm{rpm}$ using $900 \mathrm{~mL}$ of $0.1 \mathrm{~N} \mathrm{HCl}(\mathrm{pH} 1.2$ ) as dissolution medium at $37 \pm 0.5^{\circ} \mathrm{C}$. Aliquots of $5 \mathrm{~mL}$ each were withdrawn at predetermined time intervals and replaced with equal volume of fresh medium [12]. Aliquots were filtered through a $0.45 \mu \mathrm{m}$ membrane filter and analyzed for drug content using double beam UV/VIS spectrophotometer (2202, Systronics, Ahmedabad, India) at $284 \mathrm{~nm}$ [13]. Drug concentration was calculated and expressed as cumulative percent of the drug released as expressed in Figure 9. The standard calibration curve of Domperidone was prepared in $0.1 \mathrm{~N} \mathrm{HCl}$. $100 \mathrm{mg}$ Domperidone was weighed and transferred in to a $100 \mathrm{ml}$ volumetric flask. Minimum quantity of methanol was used to dissolve the drug and the volume was made up to the mark with $0.1 \mathrm{~N} \mathrm{HCl}$ to obtain stock solution (A) having concentration of $1000 \mu \mathrm{g} / \mathrm{ml} .10 \mathrm{ml}$ of stock solution (A) was further diluted to 100 $\mathrm{ml}$ with $0.1 \mathrm{~N} \mathrm{HCl}$ to give a stock solution (B) of concentration $100 \mu \mathrm{g} / \mathrm{ml}$. Aliquots of the stock solution (B) was serially diluted in triplicate to obtain solutions in concentration range of 5 to $30 \mu \mathrm{g} / \mathrm{ml}$ of drug with $0.1 \mathrm{~N}$ $\mathrm{HCl}$. The absorbance of final solutions was measured at $284 \mathrm{~nm}$ (2202 double beam UV/VIS spectrophotometer, Systronics, Ahmedabad, India) using $0.1 \mathrm{~N} \mathrm{HCl}$ as blank.

Acknowledgements: The authors gratefully acknowledge Dr. Madhu Chitkara, Vice Chancellor, Chitkara University, Rajpura, Punjab, India, and Dr. Sandeep Arora, Director, Chitkara College of Pharmacy, Chitkara University, Rajpura, Punjab, India for support and institutional facilities.

Author contributions: Concept - I.S.; Design - I.S., G.A.; Supervision - I.S.; Resources - I.S.; Materials - G.A., B.S.; Data collection and processing - G.A., B.S.; Analysis and interpretation - I.S., G.A., B.S.; Literature search - I.S., B.S.; Writing manuscript - I.S., G.A.; Critical review - I.S., G.A., B.S.

Conflict of interest statement: The authors declared no conflict of interest.

\section{REFERENCES}

[1] Sipos E, Oltean AR, Szabó ZI, Rédai EM, Nagy GD. Application of SeDeM expert systems in preformulation studies of pediatric ibuprofen ODT tablets. Acta Pharm. 2017; 67(2): 237-246. [CrossRef]

[2] Aguilar JE, Garcia E, Suñe JM, Perez P, Miñarro M, Tico JR. Predicting orally disintegrating tablets formulations of ibuprophen tablets: An application of the new SeDeM-ODT expert system. Eur J Pharm Biopharm. 2012; 80(3): 638648. [CrossRef]

[3] Singh I, Kumar P. Preformulation studies for direct compression suitability of cefuroxime axetil and paracetamol: A graphical representation using SeDeM diagram. Acta Pol Pharm. 2012; 69(1): 87-93.

[4] Juneja P, Kaur B, Odeku OA, Singh I. Development of corn Starch-Neusilin UFL2 conjugates as tablet superdisintegrant: Formulation \& evaluation of fast disintegrating tablets. J Drug Deliv. 2014; 827035. [CrossRef]

[5] Rashid M, Al-Remawi, Leharne SA, Chowdhry BZ, Badwan A. A novel multifunctional pharmaceutical excipient: modification of the permeability of starch by processing with magnesium silicate. Int J Pharm. 2011; 411(1-2): 18-26. [CrossRef]

[6] Singh A, Singh A, Nath LK. Microwave assisted synthesis and evaluation of modified pea starch as tablet superdisintegrant. Curr Drug Del. 2011; 8(2): 203-207. [CrossRef]

[7] Silvers D, Kipnes M, Broadstone V, Patterson D, Quigley EM, McCallum R, Leidy NK, Farup C, Liu Y, Joslyn A. Domperidone in the management of symptoms of diabetic gastroparesis: Efficacy, tolerability, and quality-of-life outcomes in a multicenter controlled trial. Clin Ther. 1998; 20: 438-453. [CrossRef] 
[8] Khan A, Iqbal Z, Rehman Z, Nasir F, Khan A, Ismail M, RoohullahMohammad A. Application of SeDeM expert system in formulation development of effervescent tablets by direct compression. Saudi Pharm J. 2014; 22(5): 433444. [CrossRef]

[9] Goel H, Vora N, Tiwary AK, Rana V. Formulation of orodispersible tablets of ondansetron HCl: Investigations using glycine-chitosan mixture as superdisintegrant. YakugakuZasshi. 2009; 129(5): 513-521. [CrossRef]

[10] Singh I, Kaur B, Juneja P. Preparation and characterization of starch-metal silicate Co-precipitates--evaluation as tablet superdisintegrant. Polim Med. 2014; 44(3): 157-166.

[11] Nagpal M, Goyal A, Kumar S, Singh I. Starch-silicon dioxide coprecipitate as superdisintegrant: Formulation and evaluation of fast disintegrating tablets. Int J Drug Delivery. 2012; 4(2): 164-174.

[12] Fini V, Bergamante GC, Ceschel C, Ronchi, Moraes CA. Fast dispersible/slow releasing ibuprofen tablets. Eur J Pharm Biopharm. 2008; 69(1): 335-341. [CrossRef]

[13] Patel DM, Patel SP, Patel CN. Formulation and evaluation of fast dissolving tablet containing domperidone ternary solid dispersion. Int J Pharm Investig. 2014; 4(4): 174-182.

This is an open access article which is publicly available on our journal's website under Institutional Repository at http://dspace.marmara.edu.tr. 